\title{
Environmental and technical and economic indicators of methods of solid domestic waste recovery
}

\author{
Olga Popova ${ }^{1, *}$, Aleksandr Starcev ${ }^{1}$, Mikhail Lunyakov $^{3}$ and Natalia Fomenko ${ }^{4}$ \\ ${ }^{1}$ Northern (Arctic) Federal University named after M. V. Lomonosov, \\ Severnaya Dvina Emb. 17, 163002 Arkhangelsk, Russia \\ ${ }^{3}$ Moscow State University of Civil Engineering, 26, Yaroslavskoye sh., Moscow, 129337, Russia \\ ${ }^{4}$ National Research Nuclear University (Volgodonsk branch) 73/94 Lenin St., Rostov re- \\ gion, Volgodonsk, 347360, Russia
}

\begin{abstract}
The paper analyzes the waste recovery methods. The comparison of the recovery and processing technologies of solid domestic waste is made. The most effective technologies are proposed from the point of view of ecology, specific capital investments, profitability. Analysis of the research results showed that the pyrolysis technology for the neutralization and recovery of domestic waste is the best according to technical and economic and environmental indicators. The calculation of the economic payback is carried out using the example of the waste recovery plant construction by the pyrolysis method in the Arkhangelsk region. The calculation took into account all costs associated with the construction and operation of the plant, including capital investments, maintenance and removal of waste, as well as their storage. At the same time, the item of income was formed both at the expense of obligatory of the Arkhangelsk region resident payments for the domestic waste removal, and at the expense of additional financial revenues from electricity and secondary resources (slag, pyrolysis oil, pyro-gas) generated during the recovery process. The project payback period was 7.8 years.
\end{abstract}

\section{Introduction}

Most of the Russian Federation urbanized territories are faced with the problem of increasing of domestic and industrial waste volume. About 7 billion tons of waste are generated in the Russian Federation annually, of which only 2 billion tons are used, or 28.6 percent. [1] Over 1.9 billion tons of hazardous waste has been accumulated at landfills, dumps and other facilities owned by enterprises. [1] The assessment of the situation allows to conclude that the amount of waste generated in the country is constantly increasing.

The analysis showed that, at the moment, the main recovery technology of solid domestic and industrial wastes (SDIW) in the Russian Federation is their burial at landfills and dumps [2]. Due to the landfill shortage for the storage and burial of waste, the practice of

*Corresponding author: lncs@springer.com 
their recovery in places of unorganized storage (unauthorized dumps) is widespread, which represents a great danger to the environment [1].

First of all, the uncontrolled recovery of waste in unauthorized dumps is a source of soil pollution by harmful toxic biological substances, as well as pollution of surface waters and atmospheric air. As a result, due to uncontrolled storage of waste there is a certain threat to human health and life [3].

Thus, an important task is the environmental safety of domestic and industrial waste recovery process. However, the stumbling block in this task solving is the question of the financial (investment) feasibility of progressive environmentally safe waste recovery technologies. Compared with the most common method of waste burial, modern technologies require significant initial capital investments. At the same time, at the present time there is no consensus on which technology for SDIW recovery is the most rational [2]. This significantly influences the decision to invest in these risky construction projects.

Based on the above, the main goal of the state policy in the field of waste management is to reduce the anthropogenic load on the environment based on the organization of a system for collecting, transporting and processing waste. The purpose of this study is to select the most environmentally and economically efficient way to processing and recovery of solid domestic waste using the example of city agglomeration of ArkhangelskSeverodvinsk-Novodvinsk and Primorsky District of the Arkhangelsk Region.

The objectives of the study include carrying out an environmental and economic efficiency calculation of waste management schemes based on thermal and biothermal processing and the selection of the optimal technology for the processing and recovery of solid domestic waste (SDW).

\section{Comparative analysis of SDIW recovery technologies}

At the present time, unfortunately, there is no such technology that would allow recovering the SDIW without damaging the environment: without the production of industrial waste, emissions of harmful substances into the atmosphere. There is also no SDIW recovery technology with high economic efficiency.

There are a number of methods for processing and recovery of SDIW, including biothermal and thermal. All technologies have both cons (disadvantages) and pros (advantages), so that when choosing the appropriate technology for the waste recovery, all parameters should be considered [2].

The biothermal method consists in domestic waste recovery technology at SDIW landfills and is currently used throughout the Russian Federation. Thermal recovery method is applied only in large cities. However, only about $5 \%$ of all incoming waste is recovered of with this technology, the rest of the waste also goes to the landfill for burial [2]. 

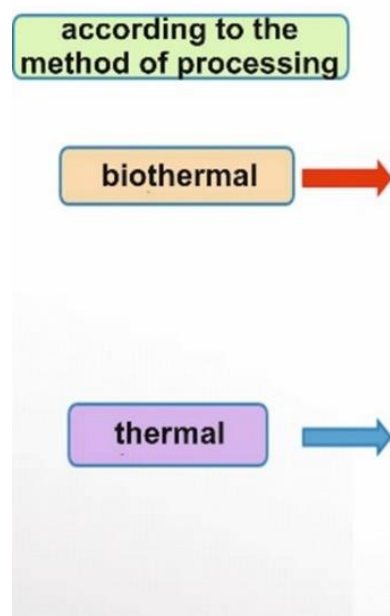

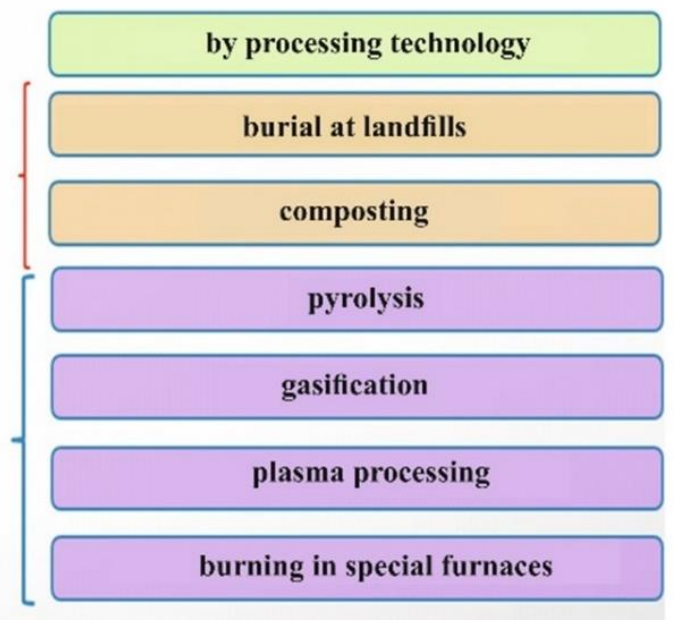

Fig. 1. Classification of SDIW recovery ways.

Table 1. presents the pros and cons of landfill burial technology. The few pros of technology are associated with a low level of costs for its organization, which has led to its widespread distribution. At the same time, the consequence seriousness of the further implementation of this SDIW recovery technology indicates the need to immediately abandon its use and the application of alternative technologies.

Table 1. Pros and cons of the biothermal recovery method [4].

\begin{tabular}{|c|c|c|}
\hline $\begin{array}{l}\text { Processing } \\
\text { technology }\end{array}$ & Pros of technology & Cons of technology \\
\hline Landfill burial & $\begin{array}{l}\text { - Low initial capital } \\
\text { investment in the } \\
\text { collection and waste } \\
\text { recovery; } \\
\text { - Low level of staff } \\
\text { skills. }\end{array}$ & $\begin{array}{l}\text { - The landfill gas (biogas) is formed as a } \\
\text { result of the vital activity of organic matter, } \\
\text { which spreads over long distances aggravat- } \\
\text { ing the ecological situation; } \\
\text { - Spontaneous ignition; } \\
\text { - Migration of chemical elements and their } \\
\text { penetration into ground water; } \\
\text { - } \quad \text { High operating costs; } \\
\text { - Does not provide bacteriological and } \\
\text { epidemiological safety; } \\
\text { - Promotes the spread of hazardous sub- } \\
\text { stances to human health; } \\
\text { - The need for reclamation. }\end{array}$ \\
\hline
\end{tabular}

There are a number of thermal methods for domestic and industrial waste processing this is pyrolysis, plasma gasification, and burning in special furnaces [4].

The Ministry of Ecology and Nature Management and the Directorate of Rational Use of Mineral Resources made a comparison of the environmental indicators of various alternative technologies of SDIW neutralization and recovery (table 2) [2].

Table 2. Comparison of environmental technology indicators of SDIW neutralization and recovery $[2]$.

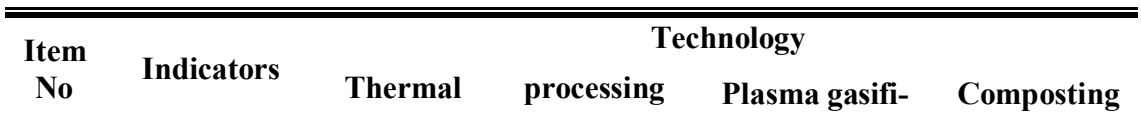




\begin{tabular}{|c|c|c|c|c|c|}
\hline & & Burning & Pyrolysis & cation & \\
\hline 1 & $\begin{array}{c}\text { Availability } \\
\text { of industrial } \\
\text { waste }\end{array}$ & $\begin{array}{c}23-28 \% \\
\text { (slag) }\end{array}$ & $\begin{array}{l}25-30 \% \\
\text { (slag) }\end{array}$ & $\begin{array}{l}\text { Low-dispersive } \\
\text { dust, sublimates } \\
\text { of heavy metals }\end{array}$ & 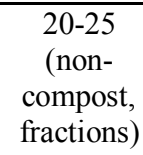 \\
\hline 2 & Soil pollution & $\begin{array}{l}\text { only a slag } \\
\text { dump }\end{array}$ & $\begin{array}{c}\text { only a slag } \\
\text { dump }\end{array}$ & practically no & $\begin{array}{c}\text { practically } \\
\text { no }\end{array}$ \\
\hline 3 & $\begin{array}{c}\text { Groundwater } \\
\text { pollution }\end{array}$ & $\begin{array}{c}\text { Нет } \\
\text { no }\end{array}$ & $\begin{array}{c}\text { Нет } \\
\text { no }\end{array}$ & $\begin{array}{c}\text { Нет } \\
\text { no }\end{array}$ & $\begin{array}{c}\text { Нет } \\
\text { no }\end{array}$ \\
\hline 4 & $\begin{array}{l}\text { Atmosphere } \\
\text { pollution }\end{array}$ & $\begin{array}{l}\text { within the } \\
\text { normal } \\
\text { range }\end{array}$ & $\begin{array}{l}\text { within the } \\
\text { normal } \\
\text { range }\end{array}$ & heavy metals & $\begin{array}{c}\text { within the } \\
\text { normal } \\
\text { range }\end{array}$ \\
\hline
\end{tabular}

Comparing the technologies according to their environmental indicators, it can be concluded that the technologies of pyrolysis, burning, plasma gasification and composting, while observing all the technological aspects, do not pollute groundwater, and the atmosphere pollution occurs only during plasma gasification. As for soil pollution, according to the data in the table above, there is practically no pollution. When using technologies for burning and pyrolysis, it is possible to use the resulting slag for the production of building materials, which increases the payback on these technologies.

The composting technology related to the biothermal method of recovery, although it has significant advantages over the landfill burial technology, but cannot fully ensure environmental safety. In addition, only $50 \%$ of the total mass of waste can be composted after pre-sorting (or selective waste collection). The rest of the waste must be recovered by one of the above methods (technologies). Therefore, in our opinion, composting technology is an intermediate stage between sorting and recovery and is more related to waste processing. I.e. this technology cannot exist without preliminary operations of waste sorting and subsequent recovery of non-compostable waste. Therefore, composting is not included in further comparative analysis of SDW recovery technologies.

\section{Economic efficiency evaluation of SDW recovery technologies}

Economic efficiency calculation of SDIW recovery technologies was made on the example of the Arkhangelsk region.

For the calculation used the following data:

- according to the government data of the Arkhangelsk region, 269 thousand tons of SDW are collected annually by the population living in apartment buildings and individual residential buildings [5];

- the electric energy tariff for legal entities according to the Agency for Tariffs and Prices of the Arkhangelsk Region from July 1, 2017 through December 31, 2017 is 4.77 rubles per $\mathrm{kWh}$;

- the approximate amount of environmental payments in the Arkhangelsk region is 2,250 rubles per ton of recovery waste.

\subsection{The construction and operation costs of the SDW recovery enterprises}

Technical-economic enterprise indicators of various waste processing and recovery technologies presented in table 3 . 
Table 3. Specific technical-economic enterprise indicators of waste processing and recovery (per 1 ton of SDW) [2].

\begin{tabular}{|c|c|c|c|c|c|}
\hline \multirow{3}{*}{$\begin{array}{l}\text { Item } \\
\text { No }\end{array}$} & \multirow{3}{*}{ Indicators } & \multirow{3}{*}{$\begin{array}{l}\text { Measurement } \\
\text { units }\end{array}$} & \multicolumn{3}{|c|}{ Technology } \\
\hline & & & \multicolumn{2}{|c|}{ Thermal processing } & \multirow{2}{*}{$\begin{array}{c}\text { Plasma } \\
\text { gasification }\end{array}$} \\
\hline & & & Burning & Pyrolysis & \\
\hline 1 & $\begin{array}{c}\text { Specific invest- } \\
\text { ment }\end{array}$ & $\begin{array}{c}\text { thousand ru- } \\
\text { bles/t per year }\end{array}$ & $17-30$ & $14-20$ & $20-24$ \\
\hline 2 & $\begin{array}{l}\text { Specific cost of } \\
\text { processing }\end{array}$ & rubles/t & $700-1200$ & $600-1100$ & $1800-2300$ \\
\hline 3 & $\begin{array}{l}\text { Unit operating } \\
\text { costs }\end{array}$ & rubles/t & $1500-2000$ & $1300-1800$ & $2000-2500$ \\
\hline 4 & $\begin{array}{l}\text { Specific envi- } \\
\text { ronmental pay- } \\
\text { ments }\end{array}$ & rubles/t & 78 & 69 & 20 \\
\hline 5 & $\begin{array}{l}\text { Specific energy } \\
\text { costs }\end{array}$ & $\mathrm{kWh} / \mathrm{t}$ & $50-70$ & $50-70$ & 500 \\
\hline 6 & $\begin{array}{l}\text { Specific occu- } \\
\text { pied area }\end{array}$ & $\mathrm{m}^{2} / \mathrm{t}$ per year & $0.1-0.2$ & $0.15-0.30$ & $0.1-0.2$ \\
\hline
\end{tabular}

Table 4 presents the technical-economic enterprise indicators of various SDW processing and recovery technologies, calculated on the basis of the initial data for the Arkhangelsk region.

Table 4. Technical-economic indicators of the waste processing and recovery enterprises on the example of the Arkhangelsk region (thousand rubles).

\begin{tabular}{|c|c|c|c|c|}
\hline \multirow{3}{*}{$\begin{array}{c}\text { Item } \\
\text { No }\end{array}$} & \multirow{3}{*}{ Indicators } & \multicolumn{3}{|c|}{ Technology } \\
\hline & & \multicolumn{2}{|c|}{ Thermal processing } & \multirow{2}{*}{$\begin{array}{l}\text { Plasma gasifi- } \\
\text { cation }\end{array}$} \\
\hline & & Burning & Pyrolysis & \\
\hline 1 & Capital investment & 6456000 & 4573000 & 5918000 \\
\hline 2 & Cost of processing & 202500 & 146250 & 405000 \\
\hline 3 & Operating costs & 1066 & 893 & 6055 \\
\hline 4 & $\begin{array}{c}\text { Environmental } \\
\text { payments }\end{array}$ & 175 & 155 & 45 \\
\hline \multirow[t]{2}{*}{5} & Energy costs & 76987 & 76987 & 641565 \\
\hline & $\begin{array}{l}\text { Indicator annual } \\
\text { reduced costs }(P)\end{array}$ & 1249128 & 910235 & 1940365 \\
\hline
\end{tabular}

The indicator of the annual reduced costs (I) is the sum of the annual expenses of production (cost price) and one-time costs (capital investments), reduced to a single dimension using the coefficient of comparative economic efficiency:

$$
\mathrm{P}=\mathrm{C}+\mathrm{E}_{\mathrm{n}} \cdot \mathrm{K}
$$

where $\mathrm{P}$ is the cost price of the annual output, thousand rubles/year; $\mathrm{K}$ is the capital investment in the facility construction, thousand rubles; $E_{n}$ is the normative coefficient of comparative economic efficiency - the rate of return on investment (for calculations we assume equal to $15 \%)$.

The indicator of the annual reduced costs is calculated when there are more than two compared options. The most effective option is the one with minimal reduced costs.

Based on the results of calculation according to techno-economic indicators (Tables 3 and 4), it can be concluded that the most cost-effective technology for the SDIW processing is pyrolysis recovery technology, and the most expensive is direct combustion technolo- 
gy. At the same time, pyrolysis technology also has the lowest specific cost of processing and specific operating costs.

\subsection{Income from the operation of SDIW recovery enterprises}

Table 5 shows the specific indicators of additional income in the operation of enterprises with different SDW recovery technologies.

Table 5. Specific revenue indicators of enterprises processing and recovery waste from additional sources of income (per 1 ton of SDIW)

\begin{tabular}{|c|c|c|c|c|c|}
\hline \multirow{3}{*}{$\begin{array}{c}\text { Item } \\
\text { No }\end{array}$} & \multirow{3}{*}{ Indicators } & \multirow{3}{*}{$\begin{array}{c}\text { Measurement } \\
\text { units }\end{array}$} & \multicolumn{3}{|c|}{ Technology } \\
\hline & & & \multicolumn{2}{|c|}{ Thermal processing } & \multirow{2}{*}{$\begin{array}{c}\text { Plasma gasifi- } \\
\text { cation }\end{array}$} \\
\hline & & & Burning & Pyrolysis & \\
\hline 1 & $\begin{array}{c}\text { Production } \\
\text { steam energy }\end{array}$ & $\mathrm{MW}^{*} \mathrm{~h} / \mathrm{t}$ & 1.6 & 1.6 & - \\
\hline 2 & Electricity & $\mathrm{MW}^{*} \mathrm{~h} / \mathrm{t}$ & 0.4 & 0.3 & 0.5 \\
\hline 3 & Compost & $\begin{array}{c}\% \text { by SDIW } \\
\text { mass }\end{array}$ & - & - & - \\
\hline 4 & Ferrous metals & $\mathrm{kg} / \mathrm{t}$ & 2 & 2 & 3 \\
\hline 5 & Colored metals & $\mathrm{kg} / \mathrm{t}$ & - & $0.3-0.4$ & - \\
\hline 6 & $\begin{array}{l}\text { Other recycla- } \\
\text { bles }\end{array}$ & $\mathrm{kg} / \mathrm{t}$ & - & $5-10$ & $15-20$ \\
\hline
\end{tabular}

The enterprise revenue with various SDIW processing and recovery technologies for the Arkhangelsk region are presented in Table 6. The main volume of the enterprise revenue for processing is the payment at the tariff for waste recovery. With the same amount of recovered waste and processing rates, this indicator will be the same for all enterprises. Therefore, the amount of revenue from recovery in a comparative analysis is not considered. The second most profitable source is the generation of electricity from waste burning.

Table 6. Annual enterprise revenue of various SDW processing and recovery technologies from additional sources of income on the example of the Arkhangelsk region (thousand rubles).

\begin{tabular}{|c|c|c|c|c|}
\hline \multirow{3}{*}{$\begin{array}{c}\text { Item } \\
\text { No }\end{array}$} & \multirow{3}{*}{ Indicators } & \multicolumn{3}{|c|}{ Measurement units } \\
\hline & & \multicolumn{2}{|c|}{ Thermal processing } & \multirow{2}{*}{$\begin{array}{c}\text { Plasma gasi- } \\
\text { fication }\end{array}$} \\
\hline & & Burning & Pyrolysis & \\
\hline 1 & $\begin{array}{c}\text { Energy of production } \\
\text { steam }\end{array}$ & 2053 & 2053 & - \\
\hline 2 & Electricity & 513 & 385 & 642 \\
\hline 3 & Compost & - & - & - \\
\hline 4 & Ferrous metals & 5111 & 5111 & 7667 \\
\hline 5 & Non-ferrous metals & - & 5649 & - \\
\hline \multirow[t]{2}{*}{6} & Other recyclables & - & 77018 & 179708 \\
\hline & Total & 7677 & 90215 & 188016 \\
\hline
\end{tabular}

Comparing the incomes of enterprises with different technologies, we can conclude that the pyrolysis technology has an average level of additional income incidentally obtained when waste recovery, yielding plasma gasification. However, a comparison of the additional profitability indicators with the cost price of recovery puts it in first place in terms of profitability. Specific recovery costs using pyrolysis technology amounted to 224 million rubles with additional income of 90 million rubles. At the same time, the cost of plasma gasification is almost 5 times higher (1,053 million rubles), with an additional income of 
188 million rubles. The burning technology is also yield in terms of pyrolysis waste recovery. In addition, table 6 does not indicate slag generated by the pyrolysis and burning technology, which can be used as a building material and generate additional profit.

Thus, the pyrolysis technology of waste recovery has been adopted for further research.

\section{Calculation of economic efficiency indicators of the project to build a pyrolysis waste recovery plant}

The methodology for assessing the economic efficiency of the project for the construction of a pyrolysis SDW recovery plant is based on the concept of net present value (NPV) to assess investment returns. NPV is the current value of current and future cash flows, which can be determined by the formula (5) $[6,7]$ :

$$
N P V=\sum_{n=1}^{T} \frac{C F_{n}}{(1+i)^{n}}-I_{0},
$$

where, $T$ is the term of the investment (years); $C F_{n}$ is cash flow, i.e. the difference between income and expenditure in the year $\mathrm{n} ; I_{0}$ is the costs associated with the initial investment; $i$ is the discount rate (\%).

The calculation is performed in several stages:

1. Determination of the SDW volume in the study area, the capacity of the pyrolysis waste recovery plant and the magnitude of the initial investment and operating costs (cost price);

2. Definition of the list and calculation of the main and additional incomes of the pyrolysis waste recovery process, taking into account local conditions;

3. Calculation of economic efficiency indicators of the investment and construction project of the pyrolysis waste recovery plant in the study area.

Calculation of the economic efficiency of the pyrolysis recovery plant construction was made on the example of the implementation of a similar project on the territory of the city agglomeration of Arkhangelsk-Severodvinsk-Novodvinsk and the Primorsky District adjacent to them. The total population according to 2018 is 597371 people. ( $52 \%$ of the population of the Arkhangelsk region), an area of 46,589.54 sq. km (approximately $8 \%$ of the area of the Arkhangelsk region) (Fig. 2). 


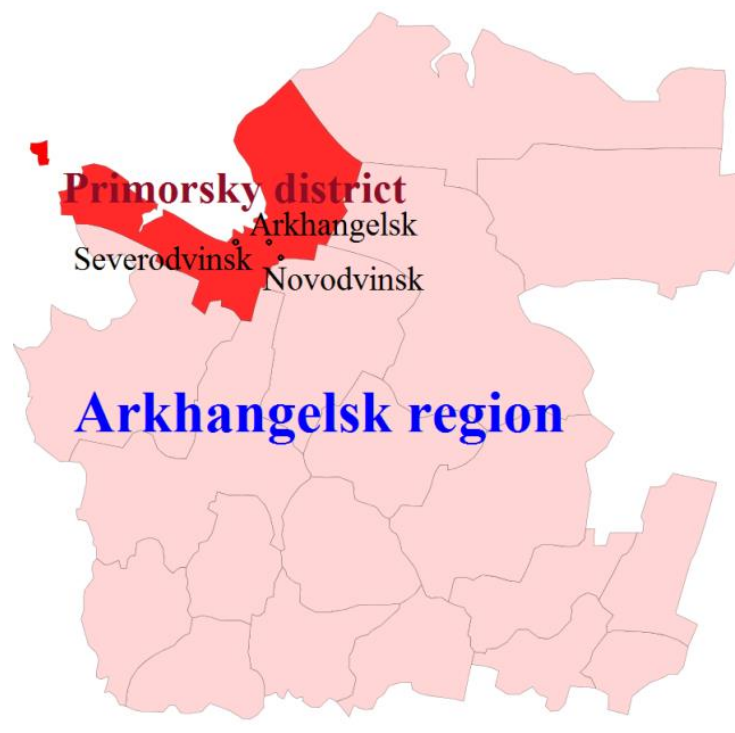

Fig. 2. Map of the study area

Stage 1 - Determination of the SDW volume in the study area, the capacity of the pyrolysis waste recovery plant and the value of the initial investment and operating costs (cost price);

According to the Collection of Specific Indicators of Production and Consumption Waste, the general accumulation rate of SDW for comfortable residential and public buildings of cities with a population of more than 100 thousand people makes 1.5 cubic m per person per year [3].

$$
M=C h_{n} \times 1,5
$$

where $\mathrm{M}$ is the amount of waste generated per year $\left(\mathrm{m}^{3}\right) ; \mathrm{Ch}_{\mathrm{n}}$ - population.

According to statistical data as of 2018, the total population of the agglomeration city is 597371 people $\left(\mathrm{Ch}_{\mathrm{n}}\right)$.

$$
M=597371 \times 1,5=896056 \mathrm{~m}^{3}
$$

According to the Compendium of Specific Indicators of Production and Consumption Waste, the average waste density ranges from 200 to 220 kilograms per $\mathrm{m}^{3}$ (Q). [3].

The amount of waste generated per year is determined by the formula (5).

$$
M_{T}=M \times Q,
$$

where $\mathrm{M}$ is the amount of waste generated per year $\left(\mathrm{m}^{3}\right) ; \mathrm{M}_{\mathrm{T}}$ is the amount of waste generated per year in tons; $\mathrm{Q}$ is an indicator of waste density.

Thus, the total regulatory amount of waste is about 190 thousand tons or 5.2 thousand tons per day.

Over the past two decades, a number of studies have been carried out on the economic assessment of energy production from waste mass through pyrolysis. The results of individual studies, including conclusions for a plant with a capacity of more than 1 ton/day, are summarized and presented in Table 7. 
Table 7. Technical and economic indicators of pyrolysis waste recovery plants (experimental facilities) $[8-16]$.

\begin{tabular}{|c|c|c|c|c|c|c|}
\hline $\begin{array}{l}\text { Plant size } \\
\text { (ton / day) }\end{array}$ & $\begin{array}{c}\text { Initial feed- } \\
\text { stock }\end{array}$ & $\begin{array}{c}\text { Capital } \\
\text { investment } \\
\text { (million \$) } \\
(\mathrm{P})\end{array}$ & $\begin{array}{l}\text { Annual Operat- } \\
\text { ing Costs (million } \\
\text { \$) (R) }\end{array}$ & $\begin{array}{c}\text { Costs of } \\
\text { works }(\$ / t) \\
(X)\end{array}$ & $\begin{array}{c}\text { Sourc } \\
\text { e }\end{array}$ & $\begin{array}{c}\text { Type of } \\
\text { pyrolysis } \\
\text { process }\end{array}$ \\
\hline 2000 & $\begin{array}{c}\text { Production } \\
\text { wastes }\end{array}$ & 200 & 12.3 & 83 & [8] & $\begin{array}{c}\text { Fast pyroly- } \\
\text { sis }\end{array}$ \\
\hline 1650 & $\begin{array}{l}\text { Wood pel- } \\
\text { lets, plastic }\end{array}$ & 180 & 12 & - & [9] & $\begin{array}{c}\text { Fast pyroly- } \\
\text { sis }\end{array}$ \\
\hline 1000 & Dry wood & 68 & 10.6 & 44 & [10] & $\begin{array}{c}\text { Fast pyroly- } \\
\text { sis }\end{array}$ \\
\hline 1000 & Wet wood & 72 & 11.3 & 30 & [9] & $\begin{array}{c}\text { Flash pyrol- } \\
\text { ysis }\end{array}$ \\
\hline 1000 & Peat & 76 & 10.2 & 20 & [11] & $\begin{array}{c}\text { Fast pyroly- } \\
\text { sis }\end{array}$ \\
\hline 1000 & $\begin{array}{l}\text { Production } \\
\text { waste }\end{array}$ & 82 & 10.2 & 42.5 & {$[11]$} & $\begin{array}{c}\text { Fast pyroly- } \\
\text { sis }\end{array}$ \\
\hline 900 & Wet wood & 46 & 9.9 & 34 & [12] & $\begin{array}{c}\text { Fast pyroly- } \\
\text { sis }\end{array}$ \\
\hline 550 & Dry wood & 48.2 & 9.6 & 45 & [13] & \begin{tabular}{|c}
$\begin{array}{c}\text { Fast pyroly- } \\
\text { sis }\end{array}$ \\
\end{tabular} \\
\hline 400 & Wet wood & 14.3 & 8.8 & 36 & [14] & $\begin{array}{c}\text { Fast pyroly- } \\
\text { sis }\end{array}$ \\
\hline 250 & Dry wood & 14 & 8.92 & 44 & [15] & $\begin{array}{c}\text { Fast pyroly- } \\
\text { sis }\end{array}$ \\
\hline 200 & Wet wood & 8.7 & 4.84 & 36 & [14] & $\begin{array}{c}\text { Fast pyroly- } \\
\text { sis }\end{array}$ \\
\hline 100 & Wet wood & 6.6 & 2.84 & 36 & [14] & $\begin{array}{c}\text { Fast pyroly- } \\
\text { sis }\end{array}$ \\
\hline 24 & Rice husks & 3.89 & 0.170 & 22 & [16] & $\begin{array}{c}\text { Fast pyroly- } \\
\text { sis }\end{array}$ \\
\hline 2,4 & Rice husks & 0.97 & 0.034 & 22 & [16] & $\begin{array}{c}\text { Fast pyroly- } \\
\text { sis }\end{array}$ \\
\hline
\end{tabular}

Although it is believed that the cost price, as a rule, decreases with an increase in the size of the installation, this statement cannot be attributed to the indicators in Table 7. There are various types of raw materials that have different physical and chemical properties, as well as different types of pyrolysis process. However, for an indicative estimate of capital and operating costs in a preliminary calculation, the use of the presented data is permissible. The change in capital investment $(\mathrm{P})$ and annual operating costs $(\mathrm{R})$ is presented in the graphs of Figure 3 and described by the equations of the trend lines. 


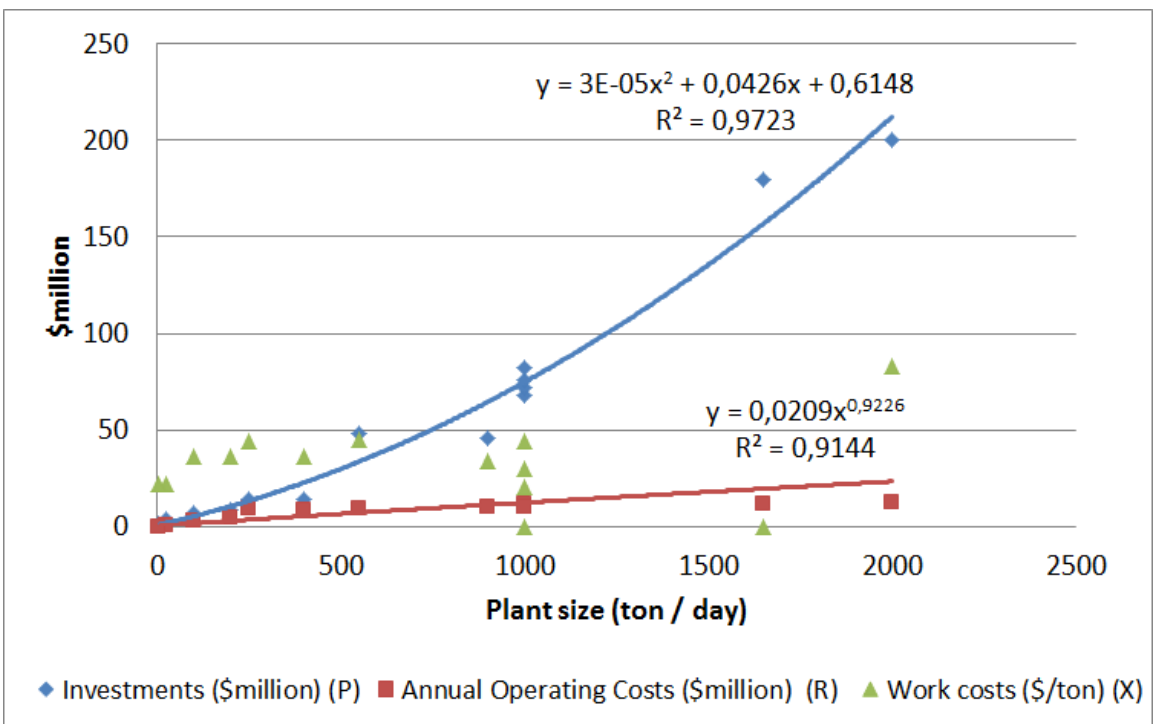

Fig. 3. Parameters of pyrolysis waste recovery plants

According to Table 7 and the trend line equations, the investment costs of the plant with an estimated capacity of 550 tons per day will be in ruble equivalent (Table 8):

Table 8. Indicators of the plant pyrolysis waste recovery for the study area

\begin{tabular}{|c|c|c|c|c|}
\hline $\begin{array}{c}\text { Plant size } \\
\text { (ton / day) }\end{array}$ & $\begin{array}{c}\text { Raw mate- } \\
\text { rials }\end{array}$ & $\begin{array}{c}\text { Investments } \\
\text { (mil.RUB) (P) }\end{array}$ & $\begin{array}{c}\text { Annual Operat- } \\
\text { ing Costs } \\
\text { (mil.RUB) }(\mathbf{R})\end{array}$ & $\begin{array}{c}\text { Work costs } \\
\text { (RUB/ton) } \\
(\mathbf{X})\end{array}$ \\
\hline 550 & ТБО & 2318 & 494 & 2520 \\
\hline
\end{tabular}

Stage 2 - Determination and calculation of the main and additional income of the pyrolysis waste recovery process, taking into account local conditions

The pyrolysis processing plant revenues include:

- population payments of the study area for the removal, maintenance and recovery of waste;

- additional electric power received in the process of pyrolysis, which can be sold to the population or enterprises located in the study area;

- secondary products derived from the pyrolysis process (slag, pyrolysis gas, pyrolysis oil, metal, carbon).

The total amount of population payments of the city agglomeration of ArkhangelskSeverodvinsk-Novodvinsk and Primorsky District for the removal, maintenance and recovery of waste will be determined by the formula (6):

$$
B=C n_{n} \times V \times 12
$$

where B is the total amount of payments per year; $\mathrm{V}$ is the tariff for the removal, maintenance and recovery of waste per month; $\mathrm{Ch}_{\mathrm{n}}$ is the population.

Thus, the amount of revenues for waste recovery (from the main activity) is 1,541 mil.RUB.

The formation of additional income from the accumulation and transmission of electricity depends on the amount of electricity produced, calculated by the formula (7):

$$
I=U \times Y \div L
$$


where I is the amount of generated electricity; $\mathrm{U}$ is the production of electricity per hour; $\mathrm{Y}$ is the amount of waste processed per hour; $\mathrm{L}$ is the capacity of installation.

The required installation capacity corresponding to the selected capacity of the pyrolysis waste processing plant with a volume of 550 thousand tons per day will be 23 tons of waste per hour respectively.

According to the data of [17], with a plant capacity of $10 \mathrm{t} / \mathrm{h}$, the amount of electricity produced will be $49.2 \mathrm{~kW} / \mathrm{h}$. Thus, according to formula 7, with a full load of 2 installations, it is possible to produce $49.2 \times 2=98.4 \mathrm{~kW} / \mathrm{h}$.

Thus, the additional income from the sale of electricity to the population can be (using the data of the agency on tariffs and prices of the Arkhangelsk region of January 1, 2019, the tariff for electrical energy for individuals in Arkhangelsk is 4.85 per kWh):

$$
S=98.4 \times 24 \times 365 \times 4.85=4180622 \text { (rubles per year) }
$$

Another one additional income type can serve as secondary products: slag, pyrolysis gas, pyrolysis oil, metal, carbon. Pyrolysis-gas can be used as a fuel in the reactor itself, while the energy release increases by $50 \%$. The formation of non-ferrous metals is $0.4 \mathrm{~kg} /$ ton and ferrous metals $2 \mathrm{~kg}$ / ton. Slag is formed $35 \%$ from 1 ton.

A preliminary calculation of the production indicators of secondary products based on the given capacity of the pyrolysis waste recovery plant for the territory in question will be approximately 2 million rubles annually.

Stage 3 - Calculation of economic efficiency indicators of the investment-construction project of the pyrolysis SDW recovery plant

Calculation of economic efficiency indicators showed that if not attracting additional investors in the person of the government and receiving only the basic income from paying at the city's agglomeration tariffs of the territory in question, the pyrolysis recovery plant will reach a payback after 7.8 years with a $15 \%$ return on investment.

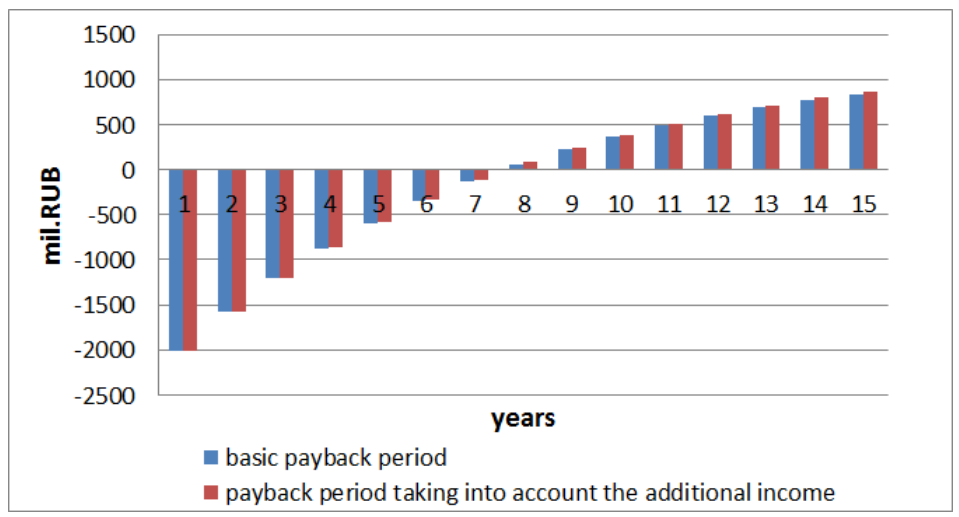

Fig. 4. Graph of net present value (NPV)

The total additional income is insignificant, so there is practically no effect on the increase in payback indicators, however, it forms the additional stability of the enterprise. Energy resources make up $1 \%$ of the total enterprise revenues, while the possibility of filling the electricity shortage in the territory in question can increase the social significance of the project. 


\section{Conclusions}

Unfortunately, at the moment, there is no ideal solution in choosing the method of SDW recover that would allow recovering the waste as environmentally safe and cost-effective as possible without the generation of additional waste in the process of recovery and emissions of pollutants into the environment.

The existing waste management system in the cities of the Russian Federation is focused on landfill burial, which leads to environmental pollution. This waste recovery method should be prohibited for use.

In the transition period to a new waste management system in conditions of low literacy and waste management culture, the lack of a system for selective collection and sorting of waste, most of the SDW will not be available for second processing for a long time. Under these conditions, thermal waste recycling technologies are the best alternative.

As a result of consideration of all the disadvantages and advantages of different technologies, as well as a result of calculations, it can be concluded that the pyrolysis technology of waste recycling is the most economically viable.

From an environmental point of view, plasma technology is the safest. But when using slag, which is formed as a result of recycling by pyrolysis and burning of waste, in secondary production (for example, the production of building materials), these technologies become environmentally safe.

The main significant disadvantage of thermal technologies for waste recovery is a significant initial one-time investment. However, the efficiency calculation presented in the study showed that with the current level of tariffs, payback occurs relatively quickly. At the same time, it should be assumed that with the development of new mechanisms for collecting, sorting and processing waste, the demand for its recovery will decrease in favor of its secondary use-processing. It is also possible to reduce tariffs. Therefore, we believe that the current time is optimal for the implementation of such investment-construction projects for waste recovery.

\section{Reference}

1. The truth about the separate collection of SDW in St. Petersburg. The status of container sites for separate collection of SDW (Saint-petersburg, Greenpeace Russia, 2007)

2. Justification of the choice of the optimal method of recovery of solid domestic waste in the cities of Russia. Federal Service for Supervision of Natural Resources (Moscow, 2012)

3. Russian Federation. Laws. On production and consumption wastes [Electronic resource]: Federal Law of 24.06.1998 N 89-FZ (as amended on 12.29.2015) ATP Consultant Plus

4. A. S. Klinkov, P. S. Belyaev, V. G. Odnolko, M. V. Sokolov, P. V. Makeev, I. V. Shashkov, Recovery and processing of solid domestic waste: study guide, 188 (Tambov: TSTU publishing house, 2015)

5. Regional program in the waste management field of production and consumption, including municipal solid waste, in the Arkhangelsk region: Approved by the Decree of the Government of the Arkhangelsk region of December 12, $556 \mathrm{pp}$. ATP Consultant Plus (2017)

6. T. Thewys, T. Kuppens, Economics of willow pyrolysis after phytoextraction. Int. J. Phytoremediat, 561-583 (2008) 
7. T. Voets, T. Kuppens, Economics of electricity and heat production by gasification or flash pyrolysis of short rotation coppice in Flanders (Belgium). Biomass Bioenergy (2011)

8. M. M. Wright, D. E. Daugaard, J. A. Satrio, R. C. Brown, Techno-economic analysis of biomass fast pyrolys to transportation fuels. Fuel, 2-10 (2010)

9. M. L. Cottam, A. V. Bridgwater, Techno-economic modeling of biomass flash pyrolysis and upgrading systems. Biomass Bioenergy, 267-273 (1994)

10. C. E. Gregoire, R. L. Bain, Technoeconomic analysis of the production of biocrude from wood. Biomass Bioenergy 275-283 (1994)

11. Y. Solantausta, A. Oasmaa, Fast Pyrolysis of Forestry Residues and Sawdust, Production and Fuel Oil Quality. In Proceedings of International Nordic Bioenergy Conference, Javaskyla, Frinland, September (2003)

12. Z. Luo, S. Wang, Y. Liao, J. Zhou, Y. Gu, K. Cen, Research on biomass fast pyrolysis for liquid fuel. Biomass Bioenergy, 455-462 (2004)

13. M. Ringer, V. Putsche, J. Scahill, Large-Scale Pyrolysis Oil Production and Economic Analysis; Technical Report NREL/TP-510-37779; National Renewable Energy Laboratory: Cole Boulevard, CO, USA (2006)

14. H. Mullaney, I. H. Farag, C. L. LaClaire, C. J. Barrett, Technical, Environmental and Economic Feasibility of Bio-Oil in New Hampshire's North Country; Final Report; New Hampshire Industrial Research Center (NHIRC): Durham City, NH, USA, (2002)

15. C. E. Gregoire, Technoeconomic Analysis of the Production of Biocrude from Wood; NREL/TP-430-5435; National Renewable Energy Laboratory: Golden, CO, USA (1992)

16. M. N. Islam, F. N. Ani, Techno-economics of rice husk pyrolysis, conversion with catalytic treatment to produce liquid fuel. Bisour. Technol, 67-75 (2000)

17. A. V. Bridgwater, J. G. Brammer, Bio Energy Research Group, Chemical Engineering and Applied Chemistry, Aston University, Birmingham, B4 7ET, UK (2015) 